\title{
RÖVID VÁGÁSFORDULÓJÚ ENERGETIKAI FAÜLTETVÉNY PÉNZÜGYI TELJESÍTMÉNYE
}

\author{
Deák Zsuzsanna - Ferencz Árpád
}

\begin{abstract}
Absztrakt: A biomassza könnyen hozzáférhetö, megújuló és környezetbarát energiaforrás. A megújuló szerves anyagok energetikai célú felhasználása világszerte növekvő tendenciát mutat igy Magyarországon is. Az erdészeti ültetvények, melyek különbözö, nagyszámú, gyorsan növö lombhullató fafajtát tartalmaznak és homogén, helyileg rendelkezésre álló nyersanyagot tudnak biztositani, széles körben elterjedtek. Kutatásaink során egy rövid vágásfordulójú energetikai faültetvény pénzügyi életképességét vizsgáltuk a kunsági régióban. Mind az EU, mind Magyarország gazdaságilag ösztönzi a bioenergia-termelő létesítmények létrehozását. Eredményeink azt mutatják, hogy a vizsgált vállalkozás nem termelt volna nyereséget támogatások nélkül. Számos akadály áll fenn a gazdálkodók előtt: például a kezdeti magas tőkeigény, a betakarítási módszerek technológiai hiányosságai, a magas logisztikai költségeǩ, illetve az elfojtott értékesítési árak.
\end{abstract}

Abstract: Biomass is an easily accessible, renewable and environmentally conscious form of resource. Utilizing renewable organic matter for energy production is a growing worldwide trend. Forest plantations that provide generous quantities of uniform, locally available raw materials from a variety of fast growing deciduous wood species are strongly promoted. In this study we have examined the financial feasibility of a short rotation energy forest plantation in the Kunság region. Both the EU and Hungary provide incentives for the establishment and dissemination of bio-energy producing facilities. Results show that without the aid of such subventions the enterprise examined would not have been financially lucrative. There are several impediments that farmers have to overcome such as high initial capital expenditures, technological shortcomings, prohibitive logistics costs and repressed sales prices.

Kulcsszavak: bioenergia, biomassza, rövid vágásfordulójú faültetvény, pénzügyi teljesítmény

Keywords: bioenergy, biomass, short rotation crop, financial feasibility

\section{Bevezetés}

Bioenergia minden olyan energia, amely biomassza átalakításából származik, ahol az közvetlenül felhasználható fütőanyagként vagy további feldolgozással folyadékká és gázokká alakitható. Az első esetben a biomasszát, elsősorban a dendromasszát égetik el erre szakosodott energetikai üzemekben, míg a második esetben mezőgazdasági eredetü állati melléktermékekből, szennyvíziszapból és települési szerves hulladékból biogázt termelnek, amelyet azután villamosenergia-termelésre vagy házon belül fütésre használnak fel. Lehetőség van arra is, hogy további tisztítás után a folyékony biogázt az országos gázhálózatokban vagy CNG-meghajtású jármủvekben hasznosítsák.

A megújuló energiaforrások jelenleg Magyarország primerenergiafogyasztásának csupán 4,9\% -át teszik ki (54,8 PJ/1000-1100 PJ/év). A megújuló energiaforrásokra vonatkozó cselekvési terv (REAP) célja, hogy 2020-ig a megújuló energiaforrásokból származó energiatermelést 13\% -ra növelje (INEMAD, 2012). Az ország legfontosabb megújuló energiaforrása a biomassza, amely az összes megújuló energia közel $90 \%$-át teszi ki. Magyarország teljes biomassza erőforrása 350-360 millió tonna. Ebből az mennyiségből 105-110 millió tonna a vegetációból származó primer biomassza, amely évente regenerálódik (Czupy et al., 2012). Ennek 
jelenleg mindössze $3 \%$-át használja fel az energiaágazat. Becslések szerint a megújuló energiaforrások $65 \%$-a hőtermelésre, $33 \%$ villamosenergia-termelésre, a többi pedig bioüzemanyag előállítására szolgál. A biomassza-potenciál eloszlása az 1. ábrán látható.

\section{1. ábra: Mezőgazdasági biomassza potenciál Magyarországon}

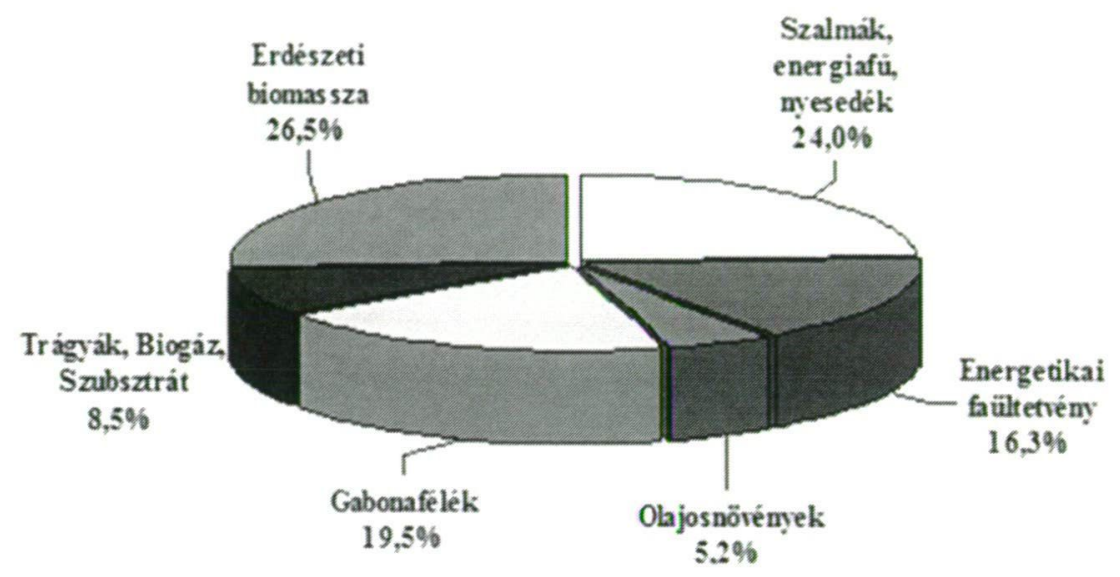

Forrás: Hajdú, 2012

Az energiaültetvények képezik az egyik legfontosabb bioenergia-forrást. Ezeken az ültetvényeken viszonylag gyorsan és nagy mennyiségben lehet dendromasszát előállítani energiatermelés céljából. Magyarországon az elmúlt években folyamatosan nőtt a rövid vágásfordulójú energiaültetvények (short rotation coppice vagy SRC) területe. A Nemzeti Élelmiszerlánc-biztonsági Hivatal (NÉBIH) adatbázisában 2012-ben 2080 hektárnyi földterületen voltak energiaültetvények, amelyek 2015-re 3268 hektárra nőttek (NÉBIH, 2015). Marosvölgyi (2004) szerint az energiaültetvények föbb jellemzői a növényi sürüség (8-15 ezer egység/ha), a bioerőművekhez hasonlítható élettartam (kb. 20 év), a jellemzően 3- 4 éves korban történő aratás, megfelelő fajok vannak még speciális területekre is, a különböző fajok száma miatt élőhely-specifikus technológiára van szükség, illetve az életciklus során 5-6 alkalommal lehet vágni és évente 150-250 GJ/ha energiatermelés érhető el.

Vágvölgyi és Czupy (2015) munkájából tudjuk, hogy Magyarországon a nyár (76\%), a füz (5\%) és az akác (9\%) képviseli a legnagyobb területet. Ami az akác teljes fogyasztását illeti, 55\% -ot használnak üzemanyagként és $45 \%$-ot ipari nyersanyagként. Ráadásul az akác a magyar méhészet és a méztermelés alapja is (Rédei et al., 2010). A nyár és a füz felaprítása kevesebb energiát igényel, és az ültetvényeket egy menetben lehet betakarítani, így több nyereség érhető el, mint az akáccal. A különböző fafajokkal végzett kísérletek alapján évente 11-20 tonna hozam érhető el hektáronként, amelyből 185-330 GJ/ha energia állítható elő. E növények termesztésének és bővítésének költségei elsősorban a helyi agroökológiai viszonyoktól, a termesztés jellegétől és a piacok közelségétől függenek. 
A megújuló energiaforrásokból származó villamosenergia-termelés 2003 után fellendült, amikor számos már meglévő széntuizelésü erőmüvet biomassza-tüzelésü és vegyes-tüzelésủ létesítményekké alakították át. A meglévő dotációs rendszer csak a megújuló energiaforrásokból származó villamosenergia-termelés támogatja, ezért az erőműveket nem ösztönözi a megtermelt hő, az energiatermelés melléktermékének, hasznosítására, még akkor sem, ha a környező távfütési rendszerek ezt könnyen felhasználhatnák. Ezen túlmenően a nagy kapacitású erömüvek általában hatalmas igényeket támasztanak a biomasszával szemben, amelyeket gyakran nagy távolságról vasúton vagy közúton kell szállítani, ezáltal hátrányosan befolyásolva az egész tevékenység energiamérlegét.

\section{Anyag és módszer}

A tanulmány során egy rövid vágásfordulójú energetikai faültetvény pénzügyi életképességének vizsgálatát végeztük el a 2009-16 időszakra. Az ültetvény egy már müködő mezőgazdasági területre épült, azzal a kifejezett céllal, hogy további bevételt biztosítson a befektetőknek és kihasználja a szinergiákat a meglévő müveletekkel. Az éves nyereséget és megtérülési időt számoltuk ki. A nyereségesség kiszámítására az ültetvény létrehozásának, és a speciális berendezések beszerzésének kezdeti beruházásait, illetve az éves erdőgazdálkodási és betakarítási költségeket, valamint az apríték értékesítéséböl származó bevételeket vettük figyelembe. Mivel a termesztés alatt álló terület nincs a gazdálkodás tulajdonában, hanem bérelt, az általánosan bevett költségszámítási gyakorlattal ellentétben a földbérleti díj költsége is szerepel a kalkulációban. Mivel a megújuló energiatermelés erősen támogatott, mind a támogatás, mind pedig a támogatás nélküli eredményeket közöljük.

\section{Eredmények és értékelésük}

Az ültetvényre felhasznált 105 hektárt egy olyan területen alakították ki, ahol gazdaságos szántóföldi növénytermesztés még uniós támogatások mellett sem érhető el. A rendelkezésre álló lehetőségekből két fő növénytípus, az energiafüz (Salix sp.), illetve a fehér akác (Robinia pseudoacacia) jöhetett szóba A vállalat olyan területen fekszik, ahol az éves átlagos csapadékmennyiség és a száraz légköri napok száma miatt a víz intenzív füzfa gazdaságos termesztése nem lehetséges. Az akác tulajdonságai viszont ideálisak ennek a technológiának az alkalmazásához, hiszen sürübb telepítés esetén magas hektáronkénti hozam érhető el. Még a gyenge minőségü homokos talajon is nő, fejlett gyökérrendszerekkel, magas szárazságtüréssel bír és erőteljes fiatalkori növekedési üteme lehetővé teszi a beruházások gyors megtérülését. Kiemelkedő regenerálódó képességének köszönhetően a betakarítási folyamat 2-3 évente megismételhető. A gyökér a betakarítás után a talajban marad, és következő tavasszal új friss hajtások sarjadnak. A fehér akác akár 15-30 méterre is megnő, és 20-40 centiméter átméröt alakít ki. Fizikai és mechanikai tulajdonságai alapján ár-érték arány tekintetében az egyik legjobb mutatókkal rendelkező fafajta. 
A frissen betakarított akác nedvességtartalma körülbelül 40-45\%, így tüzelésre akár ebben az állapotában is könnyen felhasználható. Kedvező tüzelési tulajdonságai miatt nagyobb erőmüvek és gyárak is keresik. A fő cél az volt, hogy tervezhetö és folyamatos bevételi forrást biztosítson a vállalat számára az év folyamán, még a télen is, miközben a meglévő humán erőforrásokat megtartsa és jobban kihasználja, és hosszú távon új munkahelyeket teremtsen. Ezenkívül az energiaköltségek is csökkenthetök, mivel az épületek saját aprítékkal történő felfütése jelentősen olcsóbb, mint a földgázzal történő fütés. Jövőbeli cél az apríték felhasználása a szárítógép fütésére is, ami további költségcsökkentést eredményezhet.

$\mathrm{Az}$ energetikai erdőtelepítés csak engedéllyel végezhető el, ahol szigorú kritériumokat kell teljesíteni. A vállalat a telepítési költség 40\%-át (57500 euro) igényelhette uniós támogatásként. Tekintettel arra, hogy a támogatás fó célja a helyi vállalkozások segítése volt, az első öt évben a vállalat nem használhatta saját munkaerejét a telepítés, termesztés és betakarítás céljából. Mivel az ültetést előzetesen önerőből kellett finanszírozni, a telepítés három menetben történt. Az első évben 20,5 hektárt ültettek, majd a második évben 62 hektárt, a harmadikban pedig 22,5-t.

Az energetikai célból termesztett akácfa betakarítása a telepítés nagy sürűsége és a faanyag keménysége miatt jelenleg nem rendelkezik kiforrott technológiával. A füzfa ültetvényeket könnyen be lehet takarítani egy speciális adapter segítségével. Ebben az esetben azonban a betakarítógép csak akkor képes megfelelö teljesítményre, ha csökkentik a pengék számát, ami jelentősen megnöveli a forgácsok méretét, G30-tól a G50-G60-ig, ami problémát okozhat az értékesítés során. Az alvállalkozók nem szívesen vállalkoznak 3-4 éves érett akác ültetvények betakarítására, mivel a bérmunka díjazása hektáralapon történik és a gép jelentős mértékben leamortizálódik a túlzott használat miatt. A fiatalabb ültetvények ( $1-3 \mathrm{eev}$ ) esetében azonban a 120-140 ezer forintos hektáronkénti betakarítási költség nem gazdaságos az ültetvény tulajdonosa számára, mivel a termés hozama hektáronként csak 13-16 tonna, amely nem fedezi a betakarítás, tárolás, szárítás, rakodás és szállítás együttes költségeit.

A cég G30-G50 méretủ chipeket gyárt, amelyeket mind magánszemélyek, mind gyárak és erőmüvek számára értékesíthetnek. Ez azonban csak akkor ésszerü, ha az ügyfél 50 kilométeres körzeten belül van, vagy a felvásárló telepi áron veszi át az aprítékot. A faforgács nagy méretének köszönhetően $90 \mathrm{~m}^{3}$-es specializált pótkocsis teherautókra van szuikség ahhoz, hogy gazdaságosan rövidebb távolságokra szállítsák.

Minél kisebb méretủ a termék, annál drágább a gyártás. Az apríték hatékony és gazdaságos használatához speciálisan erre a célra fejlesztett kazán szükséges. A fütöberendezések behordó rendszere könnyen elakadhat, ha a termék nem homogén, és a berendezés leáll. Ezért a kiváló minőségü, homogén faforgácsot tépett szálak nélkül kell előállítani. Az apríték nedvességtartalma szintén fontos. A termék folyamatos átforgatásával lehet elérni, hogy a forgalomba hozatalig kb. $25 \%$-os nedvességtartalma legyen. Ha az apríték átnedvesedik, gombásodás jelenik meg, 
ezért a minösége csökken és a termék nem lesz alkalmas élelmiszergyártó cégek üzemeinek fütésére a megnövekedett egészségügyi kockázat miatt.

A bevétel legnagyobb része a területalapú támogatásból származik, amely az összes bevétel 59\%-át teszi ki. Ezt követi az értékesítésből származó bevétel (21\%) és az ültetési támogatás (20\%). Mivel a támogatást euróban számolják, fontos meghatározó tényező a forint/euró árfolyam. A 2015-ös pénzügyi évtől kezdődően például a hektáronkénti teljes támogatás $10,05 \%$-kal nött a kedvezö árfolyamok miatt. 2013-ban sikeres pályázat eredményeképpen a vállalat 50\%-os támogatást nyert egy új, speciális betakarító géphez, amellyel a termelés olcsóbb lett. A számítások az 1. és 2. táblázatban találhatóak.

1. táblázat: Az ültetvény költségei és bevételei támogatással ( $\mathrm{E}$ forint)

\begin{tabular}{|c|c|r|r|r|r|r|}
\hline $\mathbf{E v}$ & $\begin{array}{c}\text { Terület } \\
(\mathrm{Ha})\end{array}$ & $\begin{array}{c}\text { Mennyiség } \\
\text { (tonna) }\end{array}$ & Költség & Árbevétel & Nyereség & Halmozott \\
\hline $\mathbf{1}$ & & & 8024 & 4024 & -4000 & -4000 \\
\hline $\mathbf{2}$ & & & 26 & 13559 & -12 & -16543 \\
\hline $\mathbf{3}$ & 13 & 195 & 16 & 11498 & -4964 & -21507 \\
\hline $\mathbf{4}$ & & & 4325 & 6154 & 1830 & -19677 \\
\hline $\mathbf{5}$ & & & 2940 & 7245 & 4305 & -15372 \\
\hline $\mathbf{6}$ & 28 & 593 & 5892 & 13104 & 7212 & -8160 \\
\hline $\mathbf{7}$ & 20 & 420 & 5146 & 12099 & 6953 & -1208 \\
\hline $\mathbf{8}$ & 20 & 420 & 5146 & 12007 & 6860 & 5652 \\
\hline
\end{tabular}

Forrás: saját számítások

Az 1. táblázatból látható, hogy a kezdeti uiltetési éveket kivéve a vállalkozás a támogatásoknak köszönhetően nyereséges volt. Az elemzett idöszakban az adott támogatási szint mellett a beruházás a 8 . évben térült meg.

2. táblázat: Az ültetvény költségei és bevételei támogatás nélkül ( $\mathrm{E}$ forint)

\begin{tabular}{|c|r|r|r|r|r|r|}
\hline $\mathbf{E} \mathbf{v}$ & $\begin{array}{c}\text { Terület } \\
(\mathrm{Ha})\end{array}$ & $\begin{array}{c}\text { Mennyiség } \\
\text { (tonna) }\end{array}$ & Költség & Árbevétel & Nyereség & Halmozott \\
\hline $\mathbf{1}$ & & & 8024 & 0 & -8024 & -8024 \\
\hline $\mathbf{2}$ & & & 26102 & 0 & -26102 & -34126 \\
\hline $\mathbf{3}$ & 13 & 195 & 16462 & 1950 & -14512 & -48638 \\
\hline $\mathbf{4}$ & & & 4325 & 0 & -4325 & -52962 \\
\hline $\mathbf{5}$ & & & 2940 & 0 & -2940 & -55902 \\
\hline $\mathbf{6}$ & 28 & 593 & 5892 & 5926 & 34 & -55868 \\
\hline & & & & & & \\
\hline $\mathbf{7}$ & 20 & 420 & 5146 & 4200 & -946 & -56815 \\
\hline $\mathbf{8}$ & 20 & 420 & 5146 & 4200 & -946 & -57761 \\
\hline
\end{tabular}

Forrás: saját számítások 
Támogatások nélkül azonban a vállalat mintegy egy millió forint éves veszteséget generál. Az éves fedezeti pont csak akkor lenn elérhető, ha a terméket 22,5\%-kal drágábban, vagyis legalább $12250 \mathrm{Ft} /$ tonna áron értékesíthetnék.

\section{4. Összegzés}

Megállapítható, hogy a fehér akác mint rövid vágásfordulójú energetikai faanyag kockázatos befektetés, mivel a karbantartási és betakarítási költségek magasak, az eladási árak alacsonyak, a beruházás megtérülése megkérdőjelezhető. Az energetikai faültetvényeken alkalmazott technológiák még nem teljesen kiforrottak. Számos problémát és hiányosságot kell megoldani, mielőtt azok hatékonyan müködtethetők lennének. Mivel a hazai biomassza-termelést hasznosító erőmüvek száma korlátozott, a dendromassza iránti hazai piaci kereslet nem elég megbízható. A szilárd biomassza, és különösen a faenergia, fogyasztást fỏként az időjárás-függő fütési igények, illetve a világpiaci olajárak diktálják, amelyek az elmúlt években meglehetősen alacsonyak voltak. A 2016-os tél például szokatlanul kemény volt, ami az országban általános tüzifahiányt eredményezett. A 2009-2016 közötti időszakban az energiaültetvények legnagyobb bevételi forrása a területalapú támogatásból származott. Az akác energiatakarékossága a jelenlegi technológia és az eladási árak mellett támogatás nélkül nem gazdaságos, és évente jelentős veszteségeket okoz. Az éves müködési költségek fedezésére az értékesítési ár 20-25\% körüli emelésére lenne szükség (vagy hasonló termelési költségcsökkentést kellene megvalósítani).

A betakarítási technológiai fejlődése, illetve az energia hasznosítása nem csak villamosenergia termelésre, hanem közvetlenül a fogyasztói hálózatra történő bekötése is jelentősen megnövelné az energiafelhasználás hatékonyságát, csökkentené a termelési költségeket, és ezáltal az egész folyamatot környezeti szempontból semlegessé tehetné. Másrészt a bio-metán vagy a bio-hidrogén termelés technológiai elörehaladása és az elsődleges biomassza (például az erdök vagy az energianövények) melléktermékekkel és hulladékokkal való helyettesítésének tendenciája hátrányosan befolyásolhatja a SRC-termékek forgalomképességét. A bioenergia jelenleg csak akkor versenyképes a hagyományos energiaforrásokkal, ha az elemzés során a társadalom számára biztosított minden előnyét figyelembe vesszük. Ilyen elönyök lehetnek például, hogy növelheti a mezögazdaság multifunkcionalitását, nagyobb pénzügyi stabilitást biztosíthat a termelők számára, vagy további gazdasági bevételeket és munkahelyeket hozhat a vidéki közösségek számára.

\section{Irodalomjegyzék}

Czupy I., Vágvölgyi A., Horváth B. (2012): The Biomass Production and its Technical Background in Hungary In: Proceedings of 45th International Symposium on Forestry Mechanization:

"Forest Engineering: Concern, Knowledge and Accountability in Today's Environment", Dubrovnik, Croatia, 1-9.

Hajdú J. (2012): Biogázüzemek Magyarországon, Agrárágazat, 13 (8): 118-122.

INEMAD (2012): Trágyakezelés és biogáz előállítás Magyarországon, in: INEMAD project report. $\langle$ http://www.soltub.hu/d/manure.pdf> 
Marosvölgyi, B. (2004): Magyarország biomassza-energetikai potenciálja, Energiagazdálkodás, 45 (6): 16-19.

Nemzeti Élelmiszerlánc-biztonsági Hivatal (2015): Energetikai fásszárú fa- ültetvények Magyarországon, <http://portal.nebih.gov.hu/documents/10182/ 206281/Energia_erdok_201305.pdfY>

Rédei K., Veperdi I., Tomé M., Soares P. (2010): Black Locust (Robinia pseudoacacia L.) ShortRotation Energy Crops in Hungary: A Review, Silva Lusitana, 18 (2): 217-223.

Vágvölgyi, A., Czupy, I. (2015): Energetikai faültetvények gépesítési gyakorlata Erdö-mező online: <http://erdo-mezo.hu/2015/09/12/energetikai-faultetvenyek-gepesitesi-gyakorlata/> 